\title{
Evaluation of the phenolic contents and antibacterial activity of different concentrations of Onosma chlorotricum Boiss.
}

\author{
BEHROOZ DOUSTI *, FATEMEH NABIPOR \\ Department of Biology, Islamic Azad University, Khorramabad Branch, Khorramabad, Iran
}

\begin{abstract}
Because of side effects and increasing resistance to antibiotics, considerable attention hasbeen given to extract sand biologically active compounds isolated from medicinal plants. In the present study, phytochemical screening and antibacterial activities of different concentrations of various extracts of Onosma chlorotricum were evaluated and compared with those of vancomycin and amikacin. Total phenolic and flavonoid contents and the antibacterial activity of methanol, n-hexane, and aqueous extracts $(5 \mathrm{mg} / \mathrm{ml}$ to $0.156 \mathrm{mg} / \mathrm{ml}$ final concentration) of $O$. chlorotricum against Staphylococcus aureus, Pseudomonas aeruginosa, and Escherichia coli were evaluated using disc diffusion and microdilution methods. Total phenolic and flavonoid contents were determined according to the Folin-Ciocalteu and aluminum chloride colorimetric assays, respectively. The results showed that the total phenolic and flavonoid contents of these extracts ranged from $56.10 \pm 0.13$ to $74.12 \pm 0.05 \mathrm{mg} \mathrm{GAE} / \mathrm{g}$ dry extract and from $19.3 \pm 0.6$ to $23.20 \pm 0.41 \mathrm{mg} \mathrm{QE} / \mathrm{g}$ dry extract, respectively. The methanol extract with the highest phenolic and flavonoid content showed the highest antibacterial activity against all the tested bacterial strains, with the highest inhibition zone of $21 \pm 0.7 \mathrm{~mm}$ and the lowest MIC and MBC values of $78.12 \mu \mathrm{g} / \mathrm{ml}$ for $S$. aureus. The antibacterial effects and the total phenolic content of $O$. chlorotricum were remarkable. The results suggest that the effects of methanol extract on wound healing could be tested in an animal model.
\end{abstract}

Key words: phenolic compounds, flavonoids, antibacterial activity, Onosma chlorotricum

\section{Introduction}

Infectious diseases are one of the most important causes of mortality, especially in third world countries. Several synthetic antibiotics are used to control hospital infections and infectious diseases worldwide. However, the inappropriate, irregular, and irrational use of antibiotics has led to the emergence of antimicrobial resistance (Anand et al., 2019).One of the most important challenges in the pharmaceutical industry is the increase in the incidence of infectious diseases due to bacterial resistance to antibiotics. Gram-positive bacteria such as Staphylococcus species and gram-negative bacteria such as Pseudomonas species and Escherichia coli are some examples of drug-resistant bacteria (Miranda-Arámbula et al., 2017; Hewer et al., 2017). Because of side effects and the emerging resistance of pathogenic microorganisms to antibiotics, considerable attention has been given to biological extracts and active compounds isolated from medicinal plants (Anand et al., 2019; Batiha et al., 2020; Chassagne et al., 2021). Medicinal plants are rich in a wide variety of secondary metabolites such as tannins, terpenoids, alkaloids, and flavonoids, which are reported to show antimicrobial properties in vitro (Parastoo et al., 2012; Othman et al., 2019). The genus Onosma L. belongs to the Boraginaceae family and comprises 150 species growingmainly in the western and central regions of Asia and the Mediterranean region (Rechinger, 1967). In recent years, several new species of Onosma have been reported (Binzet et al., 2010; Aytac and Turkmen, 2011; Almasi and Ranjbar, 2015; Cecchi et al., 2016; Binzet and Eren, 2018; Mehrabian and Mozaffarian, 2018), which has increased the total number of Onosma species to nearly 240 (He et al., 2020). The roots of Onosma have been widely used in tradi-

\footnotetext{
* Corresponding author: Department of Biology, Faculty of Basic Science, Islamic Azad University Khorramabad Branch, Khorramabad, Iran; e-mail: doostybehrooz@yahoo.com
} 
tional medicine for treating wounds, burns, dyspnea, hoarseness, hemorrhoids, abdominal aches, and stomach ulcers (Binzet and Akcin, 2012; Hemmati et al., 2018). Phytochemical investigation of the roots of Onosma led to the discovery of a series of shikonin and alkannin derivatives (Kretschmer et al., 2012) as compounds with a wide spectrum of biological properties such as wound healing (Madanid and Shokoohiniac, 2017), anti-inflammatory and anti-oxidant (Kumar et al., 2017), anti tumor (Hasenoehrl et al., 2017), antiviral (Chen et al., 2003), and antibacterial and antifungal properties (Ahmad et al., 2009; Zarghami Moghaddam et al., 2012). The aerial parts of the Onosma plant contain pyrrolizidine alkaloids (Damianakos et al., 2013; El-shazly et al., 2014) and phenolic compounds (Gharib et al., 2016; Ozer et al., 2017; Khaledi et al., 2018). Additionally, species of this genus contain secondary metabolites such as alkaloids, naphthoquinones, polyphenols, phytosterols, and fatty acids, which exhibit antioxidant and antimicrobial activities (Kumar et al., 2020). The species $O$. chlorotricum shows antioxidant and anti-inflammatory properties and contains phenolic compounds, compounds with phenylpropanoid and naphthoquinone structures, terpenoids, alkannin, and shikonin and its derivatives (Sut et al., 2017). This species has been used by the rural healers of Lorestan province in healing wounds and burns (Namjoyan et al., 2012).

The present study therefore aimed to determine suitable solvents for the extraction of phytochemicals; to perform phytochemical screening and quantitative analysis of total phenol and flavonoid contents; and to assess the antibacterial activities of various extracts of $O$. chlorotricum against Staphylococcus aureus, Pseudomonas aeruginosa, and Escherichia coli and compare these activities with those of vancomycin and amikacin. Our results provide the basis for future studies on the isolation, identification, and characterization of active compounds with potential applications in drug development.

\section{Materials and methods}

\section{Bacterial strains}

The microorganisms used for the antimicrobial activity screening were one gram-positive and two gramnegative bacterial species, including $S$. aureus ATCC 25923, $P$. aeruginosa ATTC 27853 , and $E$. coli ATTC 25922. The bacterial species were obtained from Iranian
Research Organization for Science \& Technology, Tehran city (IROST).

\section{O. chlorotricum plant material collection}

The whole plants of $O$. chlorotricum were collected from the Koohdasht region in southwestern Iran in July 2016. Koohdasht is located in the western part of Lorestan province, at the height of $1195 \mathrm{~m}$ above sea level; it has a moderate and semi-arid climate, and the soil type of this region is calcareous and clay. The plant was identified in herbarium of Khorramabad Branch, Islamic Azad University, and the species was determined using reliable sources and flora such as Ghahreman (Ghahreman, 1984) and flora of Iranica (Rechinger, 1967).

\section{Preparation of plant extracts}

The whole plants of $O$. chlorotricum were shade-dried and then chopped into fine powder. The fine powder $(50 \mathrm{~g})$ was mixed with $500 \mathrm{ml}$ of various extracts with methanol, n-hexane (Merck, Germany), and distilled water. The compounds were separately extracted by the maceration methodat $27^{\circ} \mathrm{C}$ for $72 \mathrm{~h}$. Each extract was passed through a filter paper No. 1 (Whatman, England) at the end of the extraction process. The filtrates obtained from the extracts were evaporated in adry rotary evaporator at $40^{\circ} \mathrm{C}$ and stored at $4{ }^{\circ} \mathrm{C}$.

\section{Phytochemical analysis of the extracts}

The phytochemical analysis of the extracts was performed using standard qualitative methods for the identification of various classes of active phytochemicals (Evans, 1996; Gautam et al., 2015).

\section{Test for alkaloids}

The test solution was acidified with acetic acid, and a drop of Mayer's reagent was added. A white precipitate indicated the presence of alkaloids.

\section{Test for flavonoids}

After the addition of concentrated $\mathrm{HCl}$ in the methanolic extract of the plant material, a red-colored compound appeared, which indicated the presence of flavonoids.

\section{Test for steroids/terpenes}

The extract was mixed with $5 \mathrm{ml}$ distilled water, and $2 \mathrm{ml}$ concentrated $\mathrm{H}_{2} \mathrm{SO}_{4}$ was poured from the side of the test tube. The color of the mixture was noted. The 
appearance of violet color indicated the presence of steroids.

\section{Test for saponins}

The extracts $(0.5 \mathrm{mg})$ were boiled with water $(10 \mathrm{ml})$ for $2 \mathrm{~min}$ in a test tube and cooled. The mixture was shaken vigorously and left to stand for 2-3 min. The formation of a $1 \mathrm{~cm}$ layer of foam indicated the presence of saponins.

\section{Test for tannins}

One milliliter of the extracts was mixed with $1 \mathrm{ml}$ of distilled water, and $4-5$ drops of $1 \%$ ferric chloride were then added. A bluish-black color appeared, which disappeared after theaddition of dilute $\mathrm{H}_{2} \mathrm{SO}_{4}$ and was followed by the formation of a yellowish-brown precipitate; this indicated the presence of tannins.

\section{Test for cardiac glycosides}

Dilute sulfuric acid $(5 \mathrm{ml})$ was added to $0.1 \mathrm{~g}$ of the test extracts in a test tube, and the mixture was boiled for $15 \mathrm{~min}$ in a water bath. It was then cooled and neutralized with $20 \%$ potassium hydroxide solution. A mixture of $10 \mathrm{ml}$ of equal parts of Fehling's solution A and Fehling's solution B was added and boiled for $5 \mathrm{~min}$. A more dense red precipitate indicated the presence of glycosides.

\section{Determination of total phenolic contents of the extracts}

The amount of total phenolics in the extracts was determined according to the Folin-Ciocalteu method (Hatami et al., 2014). Briefly, $0.5 \mathrm{ml}$ of each extract was mixed with $2.5 \mathrm{ml}$ of Folin-Ciocalteu reagent $(0.2 \mathrm{~N})$. After $5 \mathrm{~min}, 2 \mathrm{ml}$ of $7.5 \% \mathrm{Na}_{2} \mathrm{CO}_{3}$ was added to each solution. The solutions were then incubated for $120 \mathrm{~min}$ at room temperature. The optical densitiesof the mixtures were measured at $760 \mathrm{~nm}$ against a blank. All the samples were analyzed in triplicate. The total phenolic contents of each sample was calculated on the basis of the calibration curve of gallic acid and expressed as gallic acid equivalent (GAE) in milligram per gram of the samples.

\section{Determination of total flavonoid contents of the extracts}

The total flavonoid contents were determined by a previously described method (Gharib et al., 2016) by using quercetin as a reference compound. Briefly, $0.5 \mathrm{ml}$ of each extract $(0.1 \mathrm{~g} / \mathrm{ml})$ was mixed with $1.5 \mathrm{ml}$ of me- thanol, $0.1 \mathrm{ml}$ of aluminum chloride (10\%), $0.1 \mathrm{ml}$ of sodium acetate $(1 \mathrm{M})$, and $2.8 \mathrm{ml}$ of distilled water. The solutions were then incubated for $30 \mathrm{~min}$ at room temperature, and their absorbance was determined at $415 \mathrm{~nm}$. All the samples were analyzed in triplicate. Subsequently, the total phenolic content of the samples was calculated on the basis of the calibration curve of quercetin and was expressed in terms of quercetin equivalent (mg of QE/g of extract).

\section{Determination of the antimicrobial activity of the extracts}

The antimicrobial activity of the methanol, n-hexane, and aqueous extracts of $O$. chlorotricum was determined by the disc diffusion and microdilution methods (Wikler, 2006).

\section{Disc diffusion method}

Antibacterial screening was performed by the disc diffusion method at the concentrations of 0.156 to $5 \mathrm{mg} / \mathrm{ml}$ of various extracts in DMSO. Mueller Hinton Agar (MHA) was inoculated with $1.5 \times 10^{8} \mathrm{CFU} / \mathrm{ml}$ of suspension of each tested bacterial strain. Sterile filter paper discs ( $6 \mathrm{~mm}$ in diameter) impregnated with $30 \mu \mathrm{l}$ of plant extracts were then placed on the surface of the plates seeded with the test organisms ( $S$. aureus, $P$. aeruginosa, and $E$. coli). A blank disc impregnated with DMSO was used as a negative control, and vancomycin and amikacin at the concentration of $30 \mu \mathrm{g} / \mathrm{ml}$ were used as positive controls. The plates were incubated at $37^{\circ} \mathrm{C}$ for $24 \mathrm{~h}$, and antibacterial activities were then determined by measuring the diameters of inhibition zones with a ruler. All the experiments were performed in triplicate.

\section{Microdilution method}

The minimum inhibitory concentration (MIC) of various extracts of $O$. chlorotricum was determined in sterile 96 -well microplates by using the broth microdilution method (CLSI, 2015). All strains were cultured in MHA and incubated at $37^{\circ} \mathrm{C}$ for $24 \mathrm{~h}$ prior to MIC determination. The inoculum density equivalent to 0.5 McFarland standard for each test organism was prepared in sterile saline. Under aseptic conditions, all the wells of microplates were filled with $95 \mu \mathrm{l}$ of Muller Hinton Broth. In the first well, $100 \mu$ of the extract dilution was added so that the concentration ranged from $39.06 \mu \mathrm{g} / \mathrm{ml}$ to $5000 \mu \mathrm{g} / \mathrm{ml}$. Next, in all the wells, except 
well no.12.5 $\mu \mathrm{l}$ of each bacterial suspension (equivalent to $0.5 \mathrm{McF}$ arland standard) was added. Well No. 11 with Muller Hinton Broth and bacterial suspension served as the positive control, and well no. 12 with Muller Hinton Broth and extracts served as the negative control. The covered microplates were then incubated at $37^{\circ} \mathrm{C}$ for $24 \mathrm{~h}$. Finally, the lowest extract concentration that inhibited the growth of the bacterial strains was considered as the MIC value of the particular extract. The wells with no visible growth were selected, and the samples were used to determine the minimum bactericidal concentration (MBC). Briefly, after homogenization, a loop of each suspension was cultured on MHA. These cultures were incubated at $37^{\circ} \mathrm{C}$ for $24 \mathrm{~h}$, and the lowest concentration with no visible growth was defined as $\mathrm{MBC}$. All the experiments were performed in triplicate.

\section{Statistical analysis}

All the experiments were conducted in triplicate. Data are expressed as mean $\pm \mathrm{SD}$. The data obtained were evaluated by one-way analysis of variance (ANOVA), and Tukey's test was performed with a $P$ value $<0.05$. The data were analyzed using SPSS software version 16 .

\section{Results}

\section{Phytochemical screening}

Phytochemical screening of $O$. chlorotricum extracts revealed the presence of alkaloids, tannins, flavonoids, terpenoids, steroids, saponins, and glycosides (Table 1).

\section{Total phenolic and flavonoid contents in $O$. chlorotricum extracts}

The results of analysis of total phenolic and flavonoid contents of the various extracts of $O$. chlorotricum are presented in Table 2.

The phenolic content $(74.12 \pm 0.05 \mathrm{mg} \mathrm{GA} / \mathrm{g})$ was the highest in the methanol extract, followed by n-hexane extract $(63.29 \pm 0.17 \mathrm{mg} \mathrm{GA} / \mathrm{g})$ and aqueous extract $(56.10 \pm 0.13 \mathrm{mg} \mathrm{GA} / \mathrm{g})$. Significant differences in the concentrations of total phenolics were noted between the methanol and n-hexane extracts as compared to the aqueous extract $(P<0.05)$.The flavonoid contents in the methanol and n-hexane extracts were higher than those in the aqueous extract $(P<0.05)$. Altogether, the highest phenolic and flavonoid contents were observed in the methanol extract $(74.12 \pm 0.05 \mathrm{mg} \mathrm{RU} / \mathrm{g}$ and $23.20 \pm$ $\pm 0.41 \mathrm{mg} \mathrm{RU} / \mathrm{g}$, respectively). It was also observed that the total phenolic and flavonoid contents of the methanol extracts were higher than those of the aqueous extracts $(P \leq 0.05)$.

\section{Antimicrobial activity of $O$. chlorotricum extracts}

In the present study, the antibacterial activity of various extracts of $O$. chlorotricum was compared with that of vancomycin and amikacin against three bacterial strains: $S$. aureus, $P$. aeruginosa, and $E$. coli. The effects of different concentrations of each $O$. chlorotricum extract on the three bacterial species were compared using the disc diffusion method, and the results are presented in Tables 3, 4, and 5. The results of the antibacterial assay performed by the microdilution method are shown in Table 6.

The effects of the different concentrations of various extracts of $O$. chlorotricum on each bacterial strain tested in comparison with the antibiotics vancomycin and amikacin are shown in Figures 1 to 4 . The results showed that all $O$. chlorotricum extracts exerted antibacterial effects at different concentrations. The antibacterial activity increased with the increase in the concentration of the testedextracts $(P \leq 0.05)$. The various extracts, however, differed considerably in their activity against the tested bacterial strains. No inhibition zone was observed for DMSO used as the negative control, whereas vancomycin had the widest inhibitory zones of 23,10 , and $16 \mathrm{~mm}$ for $S$. aureus, $E$. coli, and $P$. aeruginosa, respectively. Amikacin also had the widest inhibitory zones of 16,21 , and $23 \mathrm{~mm}$ for $S$. aureus, E. coli and $P$. aeruginosa, respectively.

All extracts at different concentrations were more effective against $S$. aureus, but were less effective against $P$. aeruginosa. The sensitivity order was as follows: $S$. aureus $>$ E. coli $>$ P. aeruginosa (Tables 3, 4, and 5).

When the antibacterial activities of the standard antibiotics and $O$. chlorotricum extracts were compared, it was observed that methanol extract at $5,2.5,1.25$, and $0.625 \mathrm{mg} / \mathrm{ml}$ concentrations; $\mathrm{n}$-hexane at $5,2.5$, and $1.25 \mathrm{mg} / \mathrm{ml}$ concentrations; and aqueous extract at 5 and $2.5 \mathrm{mg} / \mathrm{ml}$ concentrations had inhibitory effects against $S$. aureus, which was higher than the effect of amikacin $(16 \pm 0.4 \mathrm{~m})(P \leq 0.05)$; however, methanol and n-hexane extracts at all the concentrations tested showed inhibitory effects smaller than those of vancomycin $(23 \pm$ $\pm 0.5 \mathrm{~mm}$ ) against $S$. aureus, this difference was statistically significant at $P \leq 0.05$ (Tables 3,4 , and 5). 
Table 1. Phytochemical screening of various extracts of the plant Onosma chlorotricum

\begin{tabular}{l|c|c|c|c|c|c|c}
\hline $\begin{array}{c}\text { Extracts } \\
\text { of } \text { O. chlorotricum }\end{array}$ & Alkaloids & Tannins & Flavonoids & Terpenoids & Steroids & Saponins & Glycosides \\
\hline Methanol & + & + & + & + & + & + & + \\
\hline N-hexane & + & - & + & + & + & - & - \\
\hline Aqueous & - & + & + & + & + & + & - \\
\hline
\end{tabular}

$(+)$ present, (-) absent

Table 2. Total phenolics and flavonoids content in the various extracts of the Onosma chlorotricum

\begin{tabular}{l|c|c}
\hline $\begin{array}{c}\text { Extracts } \\
\text { of } \text { O. chlorotricum }\end{array}$ & $\begin{array}{c}\text { Total phenolics } \\
\text { [mg GAE/g dry extract] }\end{array}$ & $\begin{array}{c}\text { Total flavonoids } \\
\text { [mg QE/g dry extract] }\end{array}$ \\
\hline Methanol & $74.12 \pm 0.05$ & $23.20 \pm 0.41$ \\
\hline N-hexane & $63.29 \pm 0.17$ & $19.3 \pm 0.6$ \\
\hline Aqueous & $56.10 \pm 0.13$ & $17.16 \pm 0.16$ \\
\hline
\end{tabular}

The methanol, n-hexane, and aqueous extracts of O. chlorotricum at all the concentrations tested showed inhibitory effects against $E$. coli, which was higher than that exhibited by vancomycin $(10 \pm 0.16 \mathrm{~mm})$, but smaller than that of amikacin $(21 \pm 0.4 \mathrm{~mm})$, and the difference was significant at $P \leq 0.05$ (Tables 3,4 and 5). The methanol extract at 5 and $2.5 \mathrm{mg} / \mathrm{ml}$ concentrations and the n-hexane extract at $5 \mathrm{mg} / \mathrm{ml}$ concentration resulted in a higher inhibition zone against $P$. aeruginosa than vancomycin $(16 \pm 0.8 \mathrm{~mm})$; however, all the tested concentrations showed smaller inhibition zones than amikacin $(23 \pm 0.7 \mathrm{~mm})$, and the difference was significant at $P \leq 0.05$ (Tables 3,4 , and 5). The aqueous extracts at $5 \mathrm{mg} / \mathrm{ml}$ concentration $(16 \pm 0.5 \mathrm{~mm})$ and the methanol extract at $2.5 \mathrm{mg} / \mathrm{ml}$ concentration $(16.7 \pm 0.26 \mathrm{~mm})$ showed the same inhibition zones as vancomycin $(16 \pm 0.8 \mathrm{~mm})$ for $P$. aeruginosa.

All the tested extracts of $O$. chlorotricum were more effective against $S$. aureus, but less effective against $P$. aeruginosa. Accordingly, these results indicate that the antibacterial activity of all the tested extracts of O. chlorotricum was higher for gram-positive bacteria than for gram-negative bacteria (Fig. 1).

The results of the antimicrobial activity assays of the tested extracts showed that the methanol extract exhibited higherpotency than n-hexane and aqueous extracts against all the tested bacterial strains $(P \leq 0.05)$. Overall, a significant difference was observed between the antibacterial activities of all the tested extracts of
$O$. chlorotricum and their concentrations against the tested bacterial strains $(P \leq 0.05)$ (Fig. 1).

The MIC assay of the methanol extract of $O$. chlorotricum consistently showed stronger anti-bacterial activity than $\mathrm{n}$-hexane and aqueous extracts against the tested bacterial strains, with MIC values of $78.12,78.12$, and $156.25 \mu \mathrm{g} / \mathrm{ml}$ and $\mathrm{MBC}$ values of $78.12,156.25$, and $312.5 \mu \mathrm{g} / \mathrm{ml}$ against $S$. aureus, E. coli, and $P$. aeruginosa, respectively. The methanol extracts of $O$. chlorotricum showed the lowest MIC and MBC values of $78.12 \mu \mathrm{g} / \mathrm{ml}$ against $S$. aureus. In contrast, the aqueous extracts of O. chlorotricum showed the highest MIC and MBC values of $625 \mu \mathrm{g} / \mathrm{ml}$ against $P$. aeruginosa.

The results of the MBC assay were similar to the findings of the disc diffusion assay and MIC value determination. The ratio of $\mathrm{MBC} / \mathrm{MIC}$ for all $O$. chlorotricum extracts werebelow 4 , which is a clear indication of the high antibacterial activity of all the tested extracts (Mogana et al., 2020).

All the MIC values of the tested extracts against the bacterial strains were below $8 \mathrm{mg} / \mathrm{ml}$, indicating that the extracts exhibited potent antimicrobial activity, as shown by Fabry et al. (1998). The MIC and MBC values of the various extracts of $O$. chlorotricum against the tested bacterial strains are presented in Table 6 .

\section{Discussion}

Recently, because of the side effects of antibiotics and the appearance of drug resistance to widely used 
Table 3. The mean \pm SD of inhibitation zones ( $\mathrm{mm}$ ) from standard antibiotics and different concentration of methanol extract Onosma chlorotricum

\begin{tabular}{l|c|c|c}
\hline \multirow{2}{*}{$\begin{array}{c}\text { Concentration } \\
{[\mathrm{mg} / \mathrm{ml}]}\end{array}$} & \multicolumn{3}{c}{ Bacterial strains } \\
\cline { 2 - 4 } \multicolumn{1}{c|}{ S. aureus } & E. coli & P. aeruginosa \\
\hline 2.5 & $21.0 \pm 0.7$ & $19.5 \pm 0.3$ & $18.0 \pm 1.4$ \\
\hline 1.25 & $19.3 \pm 0.57$ & $18.3 \pm 0.57$ & $16.7 \pm 0.26$ \\
\hline 0.625 & $18.0 \pm 0.7$ & $17.0 \pm 1.0$ & $15.5 \pm 0.5$ \\
\hline 0.321 & $16.5 \pm 0.5$ & $15.7 \pm 0.36$ & $14.0 \pm 0.6$ \\
\hline 0.156 & $15.0 \pm 0.5$ & $14.0 \pm 0.4$ & $13.0 \pm 0.3$ \\
\hline Vancomycin & $14.0 \pm 0.7$ & $13.0 \pm 0.5$ & $11.7 \pm 0.2$ \\
\hline Amikacin & $23.0 \pm 0.5$ & $10.0 \pm 0.16$ & $16.0 \pm 0.8$ \\
\hline Dimethyl sulfoxide & - & - & $23.0 \pm 0.7$ \\
\hline
\end{tabular}

Table 4. The mean \pm SD of inhibitation zones $(\mathrm{mm})$ from standard antibiotics and different concentration of n-hexane extract Onosma chlorotricum

\begin{tabular}{l|l|c|c}
\hline \multirow{2}{*}{$\begin{array}{c}\text { Concentration } \\
{[\mathrm{mg} / \mathrm{ml}]}\end{array}$} & \multicolumn{3}{c}{ Bacterial strains } \\
\cline { 2 - 4 } \multicolumn{1}{c|}{ S. aureus } & $E$. coli & $P$. aeruginosa \\
\hline 2.5 & $20.0 \pm 0.7$ & $18.6 \pm 0.26$ & $17.5 \pm 0.8$ \\
\hline 1.25 & $18.5 \pm 0.86$ & $17.3 \pm 0.57$ & $16.0 \pm 0.3$ \\
\hline 0.625 & $17.0 \pm 0.3$ & $16.0 \pm 0.5$ & $15.0 \pm 0.5$ \\
\hline 0.321 & $15.7 \pm 0.26$ & $14.5 \pm 0.5$ & $13.6 \pm 0.2$ \\
\hline 0.156 & $14.6 \pm 0.4$ & $13.2 \pm 0.9$ & $12.5 \pm 0.5$ \\
\hline Vancomycin & $13.3 \pm 0.57$ & $12.0 \pm 0.4$ & $11.0 \pm 0.3$ \\
\hline Amikacin & $23.0 \pm 0.5$ & $10.0 \pm 0.16$ & $16.0 \pm 0.8$ \\
\hline Dimethyl sulfoxide & $16.0 \pm 0.4$ & $21.0 \pm 0.4$ & $23.0 \pm 0.7$ \\
\hline
\end{tabular}

Table 5. The mean \pm SD of inhibitation zones $(\mathrm{mm})$ from standard antibiotics and different concentration of aqueous extract Onosma chlorotricum

\begin{tabular}{l|c|c|c}
\hline \multirow{2}{*}{$\begin{array}{c}\text { Concentration } \\
{[\mathrm{mg} / \mathrm{ml}]}\end{array}$} & \multicolumn{3}{c}{ Bacterial strains } \\
\cline { 2 - 4 } \multicolumn{1}{c|}{ S. aureus } & $E$. coli & $P$. aeruginosa \\
\hline 5 & $18.6 \pm 0.57$ & $17.2 \pm 0.86$ & $16.0 \pm 0.5$ \\
\hline 2.5 & $17.3 \pm 0.5$ & $16.2 \pm 0.9$ & $15.0 \pm 0.7$ \\
\hline 1.25 & $16.0 \pm 0.7$ & $15.0 \pm 0.4$ & $14.0 \pm 0.5$ \\
\hline 0.625 & $15.0 \pm 0.5$ & $14.0 \pm 0.5$ & $13.0 \pm 0.3$ \\
\hline 0.321 & $14.0 \pm 0.6$ & $12.5 \pm 0.6$ & $12.0 \pm 0.6$ \\
\hline 0.156 & $12.6 \pm 0.4$ & $11.0 \pm 0.5$ & $10.5 \pm 0.5$ \\
\hline Vancomycin & $23.0 \pm 0.5$ & $10.0 \pm 0.16$ & $16.0 \pm 0.8$ \\
\hline Amikacin & $16.0 \pm 0.4$ & $21.0 \pm 0.4$ & $23.0 \pm 0.7$ \\
\hline Dimethyl sulfoxide & - & - & - \\
\hline
\end{tabular}


Table 6. Minimal inhibitory concentration (MIC) and minimal bactericidal concentration (MBC) values in $\mu \mathrm{g} / \mathrm{ml}$ of various extracts of Onosma chlorotricum

\begin{tabular}{|c|c|c|c|c|c|c|c|c|c|}
\hline \multirow{3}{*}{$\begin{array}{l}\text { Bacterial } \\
\text { strains }\end{array}$} & \multicolumn{9}{|c|}{ Various extracts } \\
\hline & \multicolumn{3}{|c|}{ methanol } & \multicolumn{3}{|c|}{ n-hexane } & \multicolumn{3}{|c|}{ aqueous } \\
\hline & MIC & $\mathrm{MBC}$ & $\mathrm{MBC} / \mathrm{MIC}$ ratio & MIC & $\mathrm{MBC}$ & $\mathrm{MBC} / \mathrm{MIC}$ ratio & $\mathrm{MIC}$ & $\mathrm{MBC}$ & $\mathrm{MBC} / \mathrm{MIC}$ ratio \\
\hline S. aureus & 78.12 & 78.12 & 1 & 78.12 & 156.25 & 2 & 156.25 & 312.5 & 1 \\
\hline E. coli & 78.12 & 156.25 & 2 & 156.25 & 312.5 & 2 & 312.5 & 625 & 2 \\
\hline P. aeruginosa & 156.25 & 312.5 & 2 & 312.5 & 312.5 & 1 & 625 & 625 & 1 \\
\hline
\end{tabular}
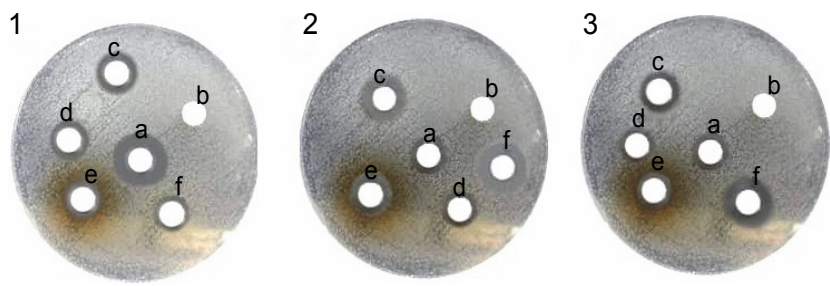

Fig. 1. Antibacterial activity of various extract of the Onosma chlorotricum against tested bacteria: 1) Staphylococcus aureus, 2) Escherichia coli, 3) Pseudomonas aeruginosa; the paper discs numbered as $\mathrm{c}, \mathrm{d}$ and e were loaded with methanol extract, n-hexane extract, aqueous extract, $\mathrm{b}$ - negative control with DMSO, f - positive control with discs containing vancomycin and amikacin

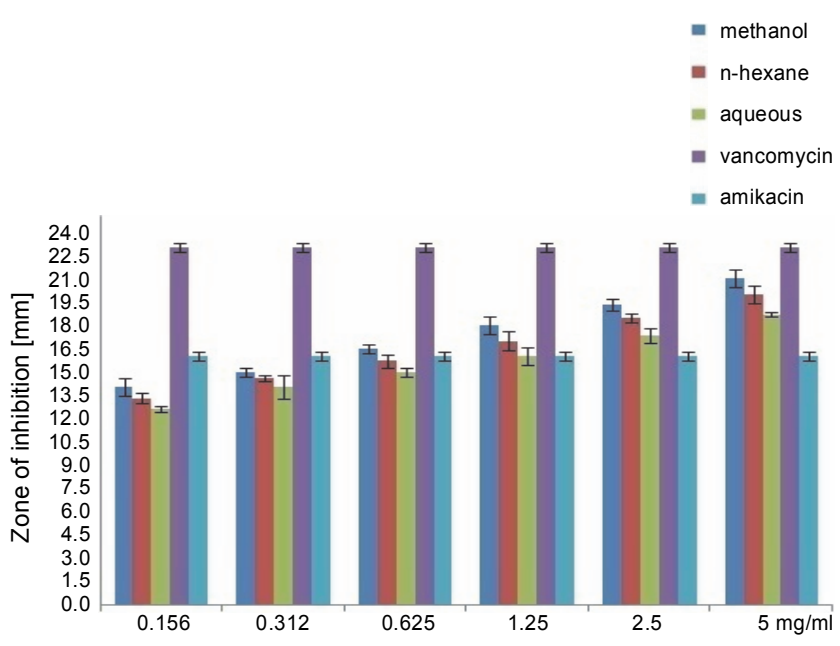

Fig. 2. Antibacterial activity of different concentration of the various extract of $O$. chlorotricum against $S$. aureus

antibiotics, much attention is being given to herbal extracts and compounds possessing various biological properties. These extracts contain natural compounds, including secondary metabolites and their derivatives (Nabipour et al., 2017). To date, no studies have been conducted on phytochemical screening and antibacterial activity of the different concentrations of $O$. chlorotricum

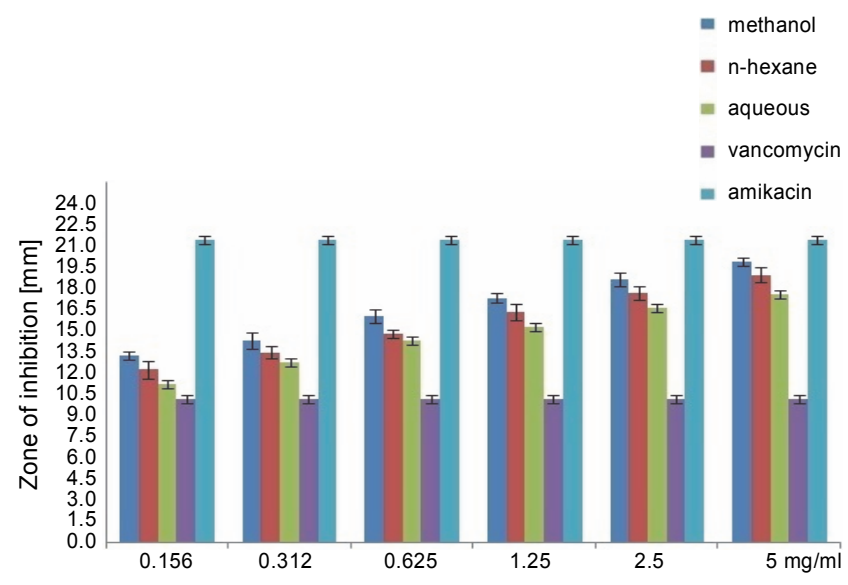

Fig. 3. Antibacterial activity of different concentration of the various extract of $O$. chlorotricum against $E$. coli

$$
\begin{aligned}
& \text { = methanol } \\
& \text { = n-hexane } \\
& =\text { aqueous } \\
& \text { = vancomycin } \\
& =\text { amikacin }
\end{aligned}
$$

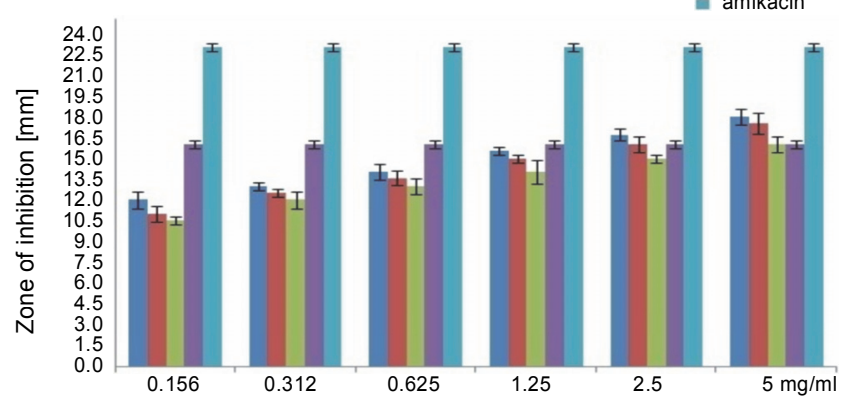

Fig. 4. Antibacterial activity of different concentration of the various extract of $O$. chlorotricum against $P$. aeruginosa

extracts. In the present study, for the first time, phytochemical screening, determination of the total phenolic and flavonoid contents, and assessment of the antibacterial activity of different concentrations of various extracts of $O$. chlorotricum were performed, and the antibacterial activity of the extracts was compared with that of two antibiotics: vancomycin and amikacin. 
To date, several studies have been conducted on the antibacterial activities of extracts obtained from other Onosma species (Ahmad et al., 2009; Zarghami Moghaddam et al., 2012).

In our present study, the results of the antibacterial activity tests showed that gram-positive bacteria were more sensitive to the extracts than gram-negative bacteria; this result is in agreement with the findings of Zarghami Moghaddam et al. (2012) who reported that the extracts of $O$. dichroanthum Boiss. inhibited grampositive bacteria more than gram-negative bacteria. Zeb et al. (2015) also reported that hot and cold water extracts of $O$. bracteatum showed the maximum activity against $S$. aureus. In the present study, the various extracts obtained from $O$. chlorotricum exhibited significantly higher activity against gram-positive bacteria such as $S$. aureus than against gram-negative bacteria such as $E$. coli and $P$. aeruginosa; this finding is in agreement with several other studies (Zeb et al., 2012; Navneet and Kumar, 2015). The reason for the higher sensitivity of gram-positive bacteria in comparison to gram-negative bacteria could be ascribed to the differences in their cell wall composition (Zarghami Moghaddam et al., 2012; Breijyeh et al., 2020). Ahmad et al. (2009) reported the antibacterial activity of $O$. griffithii. These authors showed that the degree of antibacterial activity followed the order of crude methanolic extract $>$ n-hexane extract > aqueous extract; this finding agreed with the results of our study.

Thus far, only few studies have described the phytochemical analysis of plants belonging to the genus $\mathrm{Ono}^{-}$ sma. Species of this genus contain secondary metabolites such as naphthoquinone (Vukic et al, 2017), phenolic andflavonoid compounds (Gharib et al., 2016; Ozer et al., 2017; Khaledi et al., 2018), and pyrrolizidine alkaloids (Damianakos et al., 2013; El-shazly et al., 2014), which exhibit antioxidant and antimicrobial activities ( $\mathrm{Li}$ et al., 2010; Kumar et al., 2020). Phytochemical investigation of the genus Onosma led to the discovery of a series of shikonin and alkannin derivatives (Kretschmer et al., 2012) as compounds that exhibit antimicrobial activity (Vukic et al., 2017). Therefore, the antibacterial properties of the extracts are attributed to the presence of these compounds.

The preliminary phytochemical investigation for $O$. bracteatum showed the presence of alkaloids, glyco- sides, steroids, terpenes, saponins, and tannins in methanol extract; it was also shown that the methanol extract was more potent than the other extracts against selected pathogens (Gautam et al., 2015). The extract showed the maximum activity against Streptococcus pneumoniae $(20.6 \pm 0.26 \mathrm{~mm})$ and the lowest activity against Streptococcus pyogenes $(12.6 \pm 0.28 \mathrm{~mm}$ ) (Gautam et al., 2015). In our present study, the methanol extract showed the maximum activity against S.aureus $(21 \pm 0.7 \mathrm{~mm})$ and the lowest activity against $P$. aeruginosa $(18 \pm 1.4 \mathrm{~mm})$.

In our study, the phenolic content of $O$. chlorotricum was the highest in the methanol extract $(74.12 \pm 0.05 \mathrm{mg}$ $\mathrm{GA} / \mathrm{g})$, followed by the $\mathrm{n}$-hexane extract $(63.29 \pm 0.17 \mathrm{mg}$ $\mathrm{GA} / \mathrm{g}$ ) and the aqueous extract ( $56.10 \pm 0.13 \mathrm{mg} \mathrm{GA} / \mathrm{g}$ ). The flavonoid content was higher in the methanol and n-hexane extracts $(23.20 \pm 0.41$ and $19.3 \pm 0.6 \mathrm{mg} \mathrm{GA} / \mathrm{g}$, respectively) than in the aqueous extract (17.16 \pm $\pm 0.16 \mathrm{mg} \mathrm{GA} / \mathrm{g}$ ). Khaledi et al. (2018) reported that the ethanol extract of $O$. sericeum had the total phenolic and flavonoid contents of $54.52 \mathrm{mg} \mathrm{GAE} / 100 \mathrm{~g}$ DW and $13.81 \mathrm{mg} \mathrm{RU} / 100 \mathrm{~g} \mathrm{DW}$, respectively. Thus, it can be concluded that the antibacterial activity test results obtained in the present study for O. chlorotricum extracts were correlated with their total phenolic and flavonoid contents. In addition to these factors, the structure of soil, daily and seasonal changes during the collection of plant materials, and the physiological growth cycle of the plant may cause variations in the composition of chemical compounds of the plant (Boskovic et al., 2017: Onwuka and Mang, 2018).

\section{Conclusions}

In the present study the methanol extract of $O$. chlorotricum showed the greatest antibacterial activity against the tested bacterial strains as compared to the other extracts. The total phenolic and flavonoid contents of $O$. chlorotricum methanol extract were higher than those of the other extracts. Because methanol can extract phenolic and flavonoid contents better than other solutions, the methanol extract had higher total phenolic and flavonoid contents than the other extracts. We suggest that the effects of these extracts on the in vivo wound healing parameters, including collagen deposition and other connective tissue components, should be investigated in in vivo and clinical models. 


\section{References}

Ahmad B., Ali N., Bashir S., Choudhary M.I., Azam S., Khan, I. (2009) Parasiticidal, antifungal and antibacterial activities of OnosmagriffithiiVatke. Afr. J. Biotechnol. 8(19): 5084-5087.

Almasi M., Ranjbar M. (2015) Onosmamaculata sp. nov. (Boraginaceae) from Iran. Nord. J. Bot. 33(5): 522-525.

Anand U., Jacobo-Herrera N., Altemimi A., Lakhssassi N. (2019) Comprehensive review on medicinal plants as antimicrobial therapeutics: potential avenues of biocompatible drug discovery. Metabolites 258(9): 1-13.

Aytac Z., Turkmen Z. (2011) A new Onosma (Boraginaceae) species from southern Anatolia, Turkey. Turk. J. Bot. 35(3): 269-274.

Batiha G.E.S., Olatunde A., El-Mleeh A., Hetta H.F., Al-Rejaie S., Alghamdi S., Zahoor M., Magdy Beshbishy A., Murata T., Zaragoza-Bastida A., Rivero-Perez N. (2020) Bioactive compounds, pharmacological actions, and pharmacokinetics of wormwood (Artemisia absinthium). Antibiotics 9(6): 353.

Boskovic I.D., Dukic D.A., Maskovic P.Z., Mandic L.G. (2017) Phytochemical composition and biological activity of Echium italicum L. plant extracts. Bulg. Chem. Commun. 49(4): 836-845.

Binzet R., Akcin O.E. (2012) The anatomical properties of two Onosma L. (Boraginaceae) species from Turkey. J. Med. Plants Res. 6: 3288-3294.

Binzet R., Eren Ö. (2018) Onosmaerzincanica (Boraginaceae: Lithospermeae), a new scree speciesfrom Turkey. Phytotaxa 356(2): 117-130.

Binzet R., Kandemir I., Orcan N. (2010) Palynological classification of Onosma L. (Boraginaceae) species from east Mediterranean region in Turkey. Acta Bot. Croatica 69(2): 259-274.

Breijyeh Z., Jubeh B., Karaman R. (2020) Resistance of gramnegative bacteria to current antibacterial agents and approaches to resolve it. Molecules 1340(25): 1-23.

Chassagne F., Samarakoon T., Porras G., Lyles J.T., Dettweiler M., Marquez L., Salam A.M., Shabih S., Farrokhi D.R., Quave C.L. (2021) A systematic review of plants with antibacterial activities: a taxonomic and phylogenetic perspective. Front. Pharmacol. 11: 586548.

Chen X., Yang L., Zhang N., Turpin J.A., Buckheit R.W., Osterling C., Howard O.Z. (2003) Shikonin, a component of Chinese herbal medicine, inhibits chemokine receptor function and suppresses human immunodeficiency virus type 1. Antimicrob. Agents Chemother. 47(9): 2810-2816.

Cecchi L., Coppi A., Selvi F. (2016) Onosma juliae (Boraginaceae), a new species from southern Turkey, with remarks on the systematics of Onosma in the Irano-Turanian region. Phytotaxa 288(3): 201-213.

Damianakos H., Sotiroudis G., Chinou I. (2013) Pyrrolizidine alkaloids from Onosmaerecta. J. Nat. Prod. 76(10): 1829-1835.

El-Shazly A., Wink M. (2014) Diversity of pyrrolizidine alkaloids in the Boraginaceae structures, distribution, and biological properties. Diversity 6(2): 188-282.
Evans W.C. (1996) Techniques in microscopy: quantitative microscopy. A text book of pharmacognosy. 14th ed. London: W.B. Saunders Company Ltd.: 568-578.

Fabry W., Okemo P.O., Ansorg R. (1998) Antibacterial activity of East African medicinal plants. J. Ethnopharmacol. 60(1): 79-84.

Gautam S.G., Navneet., Kumar S. (2015) Appraisal of antimicrobial properties of Onosma bracteatum Wall. fruit extracts against respiratory tract pathogens. J. Med. Herb. 1: $108-112$.

Ghahraman A. (1984) Flora of Iran. Ministry of Agriculture Jahad, Agricultural and Natural Resources Research Organization. Research Institute of Forests and Rangelands 21: 547 (in Persian).

Gharib A., Godarzee M. (2016) Determination of secondary metabolites and antioxidant activity of some boraginaceae species growing in Iran. Tropic. J. Pharmaceut. Res. 15 (11): 2459-2465.

Hasenoehrl C., Schwach G., Ghaffari-Tabrizi-Wizsy N., Fuchs R., Kretschmer N., Bauer R., Pfragner R. (2017) Anti-tumor effects of shikonin derivatives on human medullary thyroid carcinoma cells. Endocrine Connect. 6(2): 53-62.

Hatami T., Emami S.A., Miraghaee S.S., Mojarrab M. (2014) Total phenolic contents and antioxidant activities of different extracts and fractions from the aerial parts of Artemisia biennisWilld. Iran. J. Pharm. Res. 13(2): 551-558.

Hemmati A.A., Namjuyan F., Yousefi S., Housmand G.H.R., Khadem Haghighian H., Rezaei A. (2018) The healing effect of $N$-hexan, dichloromethane extract root Onosma bulbotrichum in second degree burns. World J. Plast. Surg. 7(1): 25-33.

He Y., Xu X.M., Zhou Y., Liu Q.R. (2020) Onosma fuyunensis (Boraginaceae), a new species from Xinjiang, China. PhytoKeys. 144: 11-22.

Hewer L., Smyth S.C., Alan R. (2014) Antibiotic strategies for eradicating Pseudomonas aeruginosa in people with cystic fibrosis. Cochrane Library. (11): 1-82.

Khaledi M., Khaledi F., Asadi-samani M., Gholipour A., Mahmoodi kouhi A. (2018) Phytochemical evaluation and antibacterial effects of Medicago sativa, Onosmasericeum, Parietariajudaica L., Phelomis Persica and Echinopharo, Platyloba Dc. On Enterococcus faecalis. Biomed. Res. 5(1): 1941-1951.

Kretschmer N., Rinner B., Deutsch A.J., Lohberger B., Knausz H., Kunert O. (2012) Naphthoquinones from Onosma paniculata induce cell-cycle arrest and apoptosis in melanoma cells. J. Nat. Prod. 75(5): 865-869.

Kumar N., Singh A., Sharma D.K., Kishore K. (2017) In-vitro anti inflammatory and antioxidant activity of Onosma hispidum (Ratanjot) roots. IJPBS 3(7): 30-33.

Kumar A., Varinder Kaur V., Kritika Pandit K., Hardeep Singh Tuli H.S., Katrin Sak K., Jain S.K., Satwinderjeet Kaur S. (2020) Antioxidant phytoconstituents from Onosma bracteata Wall. (Boraginaceae) ameliorate the CCl4 induced hepatic damage: in vivo study in male Wistar rats. Front. Pharmacol. 1301(11): 1-18. 
Li L., Li M.H., Xu L.J., Guo N., Wu-Lan T.N., Shi R.B. (2010) Distribution of seven polyphenols in severalmedicinal plants of Boraginaceae in China. J. Med. Plants Res. 4(12): 1216-1221.

Madanid I.K., Shokoohiniac Y. (2017) The wound healing effect of various extracts from Onosma microcarpum root in a diabetic animal model. J. Rep. Pharm. Sci. 6(1): 59-67.

Mehrabian A.R., Mozaffarian V. (2018) Seven new species of Onosma L. (Boraginaceae) with emphasis on their habitats in Iran. Taiwania 63(4): 366-388.

Miranda-Arámbula M., Olvera-Alvarado P.M., Lobo-Sánchez M., Xochipa I.P., Ríos-Cortés A.M.I., Cabrera-Hilerio1 S.L. (2017) Antibacterial activity of extracts of Stevia rebau diana Bertoni against Staphylococcus aureus, Staphylococcus epidermidis and Pseudomonas aeruginosa. J. Med. Plants Res. 25(11): 414-418.

Mogana R., Adhikari A., Tzar M.N., Ramliza R., Wiart C. (2020) Antibacterial activities of the extracts, fractions and isolated compounds from Canarium patentinervium Miq. against bacterial clinical isolates. BMC Compl Med. 55(20): 2-11.

Nabipour F., Dousti B. (2018) Comparison of the antifungal effects of various extracts of Onosma chlorotricum on Candida albicans and Candida glaberata with two antibiotics fluconazole and nystatin. Yafteh 20(1): 12-22.

Namjoyan F., Bazvand M., Azemi M.E. (2012) Antioxidant activity and phytochemical investigation of Onosma chlorotricum Boiss and Noe lipophilic extract on thin layer chromatography (TLC). Jentashapir. 15: 55-60.

Navneet S.S.G., Kumar S. (2015) Appraisal of antimicrobial properties of Onosma bracteatum Wall. fruit extracts against respiratory tract pathogens. J. Med. Herb. Ethnomed. 1: 108-112.

Onwuka B., Mang B. (2018) Effects of soil temperature on some soil properties and plant growth. Adv. Plants Agric. Res. 8(1): 34-37.
Othman L., Sleiman A., Abdel-Massih R.M. (2019) Antimicrobial activity of polyphenols and alkaloids in middle eastern plants. Front. Microbiol. 10: 911.

Ozer M.S., Kirkan B., Sarikurkcu C., Cengiz M., Ceylan O., Atılgan N., Tepe B. (2018) Onosma heterophyllum: phenolic composition, enzyme inhibitory and antioxidant activities. Ind. Crops Prod. 111: 179-184.

Parastoo K.A., Parisa K.A., Devindra S. (2012) A study of antibacterial activity of few medicinal herbs. Asian J. Plant Sci. Res. 2: 496-502.

Rechinger K.H. (1967) Flora iranica. Akademische Druck U. Verlagsanstalt: Graz, Austria. 48: 169-212. [in Persian].

Sut S., Pavela R., Kolarčik V., Cappellacci L., Petrelli R., Maggi F., Acqua S.D., Benelli G.(2017) Identification of Onosma visianii roots extract and purified shikonin derivatives as potential acaricidal agents against tetranychusurticae. Molecules 22(6): 1002.

Vukic M.D., Vukovic N.L., Djelic G.T., Popovic S.L., Zaric M.M., Baskic D.D., Kacaniova M.M. (2017) Antibacterial and cytotoxic activities of naphthoquinone pigments from Onosma visianii Clem. EXCLI J. 16: 73-78.

Wikler M.A. (2006) Methods for dilution antimicrobial susceptibility tests for bacteria that grow aerobically: approved standard. CLSI (NCCLS). 26: M7-A7.

Zeb M.A., Sajid M., Rahman T.U., Khattak K.F., Halim M. (2015) Phytochemical screening and antibacterial activity of Opuntia dillenii and Onosma bracteatum. J. Microbiol. Exp. 3(1): 00074.

Zarghami Moghaddam P.Z., Mazandarani M., Zolfaghari M.R., Badeleh M.T., Ghaemi E.A. (2012) Antibacterial and antioxidant activities of root extract of Onosma dichroanthum Boiss. in north of Iran. Afr. J. Microbiol. Res. 6(8): 1776-1781. 